\title{
PENGARUH PENAMBAHAN PEGAGAN (Centtela aciatica) SEBAGAI PAKAN ADDITIF BROILER TERHADAP PERSENTASE KARKAS DAN LEMAK ABDOMEN
}

\author{
Muthia Dewi1a, Toni Malvin1, Prima Silvia Noor², Yurni Sari Amir² \\ ${ }^{1}$ Program Studi Budidaya Ternak, Politeknik Pertanian Negeri Payakumbuh \\ 2Program Paramedik Veteriner, Politeknik Pertanian Negeri Payakumbuh \\ aEmail: mutdw@yahoo.com
}

\begin{abstract}
This study was conducted to evaluate the carcass percentage and abdominal fat of broiler chicken with added feed additive pegagan (Centella aciatica) powder on ration. This experiment was done at poultry farm and laboratory of Animal Husbandry Programme, Payakumbuh Agricultural Polytechnic from July to December 2018. The experiment was run in completely randomized design which consist of 4 feed treatments and 5 replications. Level used of $A=$ without pegagan powder; $B=1.5 \%$ pegagan powder; $C=3 \%$ pegagan powder dan $D=4.5 \%$ pegagan powder. The collected data was analyzed with ANOVA and Duncan Range test would use for post hoc multiple comparison. The result shown that body weight was significantly different $(P<0.05)$, carcass percentage and abdominal fat were no significantly different $(P>0.05)$. Body weight of broiler chicken was higher on level $D=4.5 \%$ pegagan powder. The additive compounds in pegagan as feed additive stimulated immunity of broiler chicken until provide better body weight but unaffected on carcass percentage and abdominal fat.
\end{abstract}

Keywords: broiler chicken, pegagan powder, feed additive, body weight, carcass, abdominal fat

\section{PENDAHULUAN}

Kebutuhan konsumen terhadap pangan ASUH (aman, sehat, utuh dan halal) tidak dapat ditunda lagi, sebagai konsekuensi keamanan pangan. Produk ASUH ini pada ayam broiler dimula dari proses pemeliharaan sejak awal seperti dari proses pemberian ransum, pemeliharaan dan pemotongan. Pemakaian ransum meupakan komponen terbesar dalam memberi pengaruh pada kesehatan dan pertumbuhan untuk mencapai daging yang sehat dan utuh.

Ayam sehat diartikan tidak ada infeksi atau penyakit pada ayam, maka biasanya peternakan menyuguhkan antibiotik ke dalam pakan. Hal tersebut memberi dampak lain berupa residu yang berbahaya bagi kesehatan konsumen yang mengkonsumsi dagingnya. Sementara tubuh ayam memiliki kemampuan alami menolak infeksi yaitu dengan meningkatkan produksi antibodi. Selanjutnya antibodi itu dapat dirangsang dengan pemberian bahan yang mengandung imunostimulan.

Keberdadaan bahan mengandung zat imunostimulan ini secara alami cukup banyak di alam. Hanya saja karena broiler dipelihara secara intensif sehingga broiler tidak dapat mengambil bahan tersebut dari lingkungan. Maka 
perlu ditambahkan bahan alami mengandung imunostimulan dalam pakan broiler untuk merangsang peningkatan daya tahan tubuhnya untuk perkembangan lebih baik tanpa harus mengkonsumsi bahan kimia yang merugikan ayam dan konsumen. Salah satu bahan alami yang mengandung imunostimulan adalah tanaman pigagan atau Centella asiatica yang banyak terdapat di lingkungan (Harahap, 2016 ; Siregar, dkk. 2017).

Pegagan merupakan tanaman yang mengandung senyawa-senyawa yang baik untuk kesehatan. Menurut Besung (2009), secara tradisional tanaman pegagan digunakan masyarakat sebagai tanaman obat atau herba untuk menyembuhkan luka, wasir, disentri, tuberculosis, demam, reumatik juga dikonsumsi sebagai sayuran oleh masyarakat. Tanaman pegagan mudah ditemukan di daerah persawahan dan ladang yang agak basah. Pada broiler, penggunaan tanaman pegagan sebagai perangsang antibodi perlu diberikan untuk mendukung kemampuan daya tahan tubuhnya dari infeksi penyakit, sehingga peternak tidak perlu memberikan bahan kimia tambahan yang bertolak belakang dengan pangan ASUH. Hasil uji kimia tanaman pegagan oleh Kabaruddin (2008) dalam Siregar, dkk (2017) kandungan air 12,38\%, Abu 13,17\%, Protein 8,46\%, Serat Kasar 14,69\% dan Lemak 10,0\%. Sedangkan hasil penelitian Nur dkk. (2017) diketahui kandungan protein 4,05\%, lemak 0,35\%, air $85,46 \%, 6.064 \%$, dan serat kasar 8,89\%.

\section{MATERI DAN METODA}

\section{Lokasi dan Waktu Penelitian}

Penelitian dilaksanakan di laboratorium ternak dan laboratorium kimia UPT Laboratorium dan di kandang broiler UPT Farm Politeknik Pertanian Negeri Payakumbuh. Penelitian dilaksanakan selama lebih kurang tiga bulan.

\section{Materi Penelitian}

Ayam yang digunakan adalah broiler strain Lohmann terdiri dari 100 ekor, pakan basal terdiri dari dedak halus, jagung giling, bungkil kedele, tepung ikan, bungkil kelapa, dan mineral, serta vaksin ND melalui tetes mata diumur ayam 4 hari. Alat yang digunakan antara lain kandang broiler jenis panggung, baby feeder, tempat pakan dan minum, oven, blender, ayakan, plastik, spuit dan jarum. Berikut skema proses pembuatan tepung tanaman pegagang.

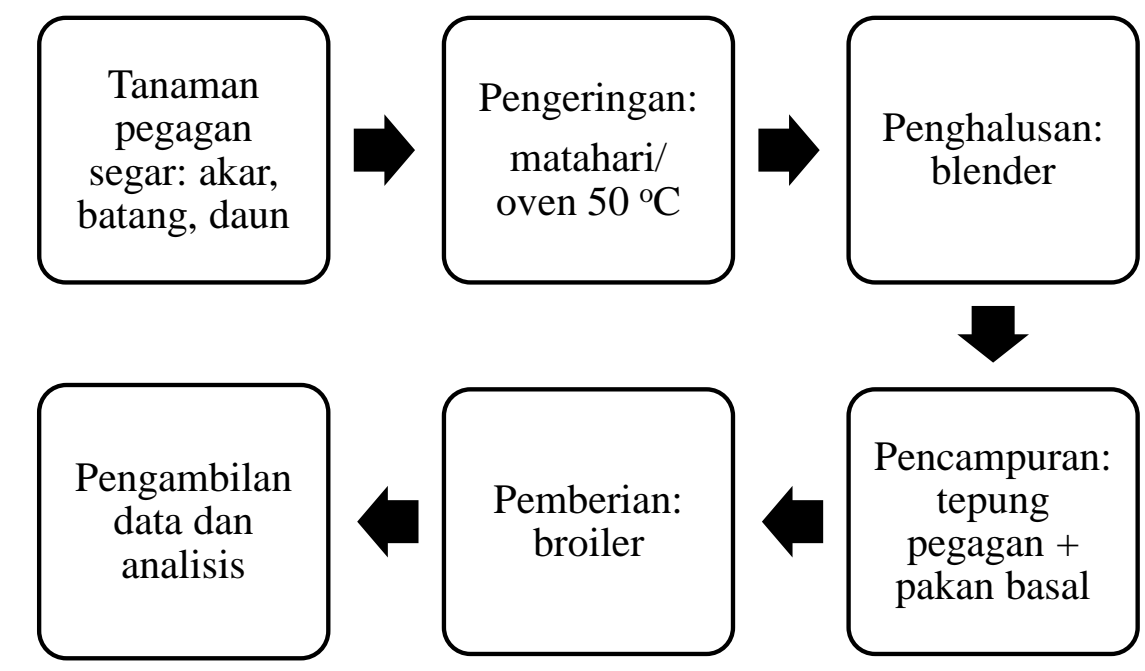


Rancangan penelitian adalah Rancangan Acak Lengkap (RAL) terdiri dari empat perlakuan dan lima ulangan, dengan perlakuan tepung tanaman pegagan (TTP) sebagai berikut A = 0\% TPG + pakan basal, B = 1,5\% TPG + pakan basal, $\mathrm{C}$ $=3 \% \mathrm{TPG}+$ pakan basal, $\mathrm{D}=4,5 \% \mathrm{TPG}+$ pakan basal. Berikut skema rancangan penelitian

\begin{tabular}{|c|c|c|c|c|}
\hline A1 & B2 & C3 & D4 & A5 \\
\hline B1 & C2 & D3 & A4 & B5 \\
\hline C1 & D2 & A3 & B4 & C5 \\
\hline D1 & A2 & B3 & C4 & D5 \\
\hline
\end{tabular}

Pakan basal merupakan pakan adukan terdiri dari dedak halus, jagung giling, bungkil kedele, bungkil kedele, bungkil kelapa, tepung ikan dan premiks. Pakan basal diformulasi dengan kandungan $\mathrm{PK} \pm 20 \%$ dan $\mathrm{EM} \pm 2800 \mathrm{kkal} / \mathrm{kg}$. Pada minggu pertama pemberian pakan berupa konsentrat komersial BR11, dilanjutkan penerapan perlakuan yaitu penambahan pegagan dalam pakan basal saat broiler umur minggu ke dua sampai minggu ke empat.

Parameter penelitian terdiri dari bobot hidup saat panen, persentase karkas dan berat lemak abdomen.

\section{HASIL DAN PEMBAHASAN}

\section{Bobot Hidup Broiler}

Bobot hidup ayam broiler merupakan bobot akhir broiler pada saat panen umur empat minggu. Rataan bobot badan ayam broiler antara 882-gram sampai 944 gram per ekor. Pemberian tepung tanaman pegagan dalam sebagai feed additive dalam ransum basal memberikan pengaruh berbeda nyata terhadap bobot badan ayam broiler $(\mathrm{P}<0.05)$. Pada perlakuan $4 \%$ tepung tanaman pegagan menghasilkan bobot badan paling tinggi dibanding tiga perlakuan lain. Namun bobot badan ayam broiler yang dihasilkan pada penelitian ini lebih rendah dibandingkan bobot broiler diumur empat minggu yaitu sekitar 1.200 gram/ekor. Rendahnya bobot badan ayam broiler dalam penelitian ini disebabkan kandungan nutrisi pakan basal juga kurang bagus yaitu protein 15.05\%, air 10.44\%, lemak 7.19\%, abu 8.98\%, serat kasar $27.77 \%$, Ca $1.94 \%$ dan P $0.87 \%$ (Laboratorium Kimia Politani Payakumbuh, 2018). Nutrisi pakan basal ketika disusun dan dihitung menggunakan data tabel untuk kadar protein $21 \%$, tetapi setelah dianalisis hanya sekitar 15\%. Ayam broiler tidak cukup mendapat nutrisi berupa protein yang dibutuhkan selama pemeliharaan. Disamping itu kandungan serat kasar pakan basal juga tinggi sehingga pertumbuhan broiler rendah.

\section{Bobot Karkas}

Pengaruh penambahan tepung tanaman pegagan terhadap bobot karkas ayam broiler adalah tidak berbeda nyata $(\mathrm{P}>0.05)$. Karkas ayam broiler menjadi perhatian untuk hasil budidaya broiler karena bisa dijadikan dasar menentukan harga seekor ayam broiler. Semakin tinggi bobot karkas broiler maka semakin mahal harganya. Bobot hidup broiler tidak sama dengan bobot karkasnya. Dimana pada saat broiler menjadi karkas maka bagian bulu, jeroan isi perut, kaki dan kepalanya sudah dibuang dan dikeluarkan. 


\section{Persentase Karkas}

Perhitungan persentase karkas broiler diperoleh dari perbandingan bobot karkas dengan bobot hidup broiler untuk setiap perlakuan. Sama halnya dengan bobot karkas, persentase karkas antar perlakuan menunjukkan pengaruh tidak nyata $(\mathrm{P}>0.05)$. Penambahan tepung tanaman pegagan dalam pakan basal selama pemeliharaan tidak mempengaruhi persentase karkas.

\section{Lemak Abdomen}

Hasil perhitungan terhadap persentase lemak abdomen ayam broiler yang ditambahkan tepung tanaman pegagan yaitu berbeda tidak nyata $(\mathrm{P}>0.05)$. Secara statistik nilai persentase lemak abdomen selama pemeliharaan adalah sama, baik yang ditambahkan maupun tidak tepung tanaman pegagan. Penggunaan tepung tanaman pegagan sebagai additif lebih rendah persentase lemak abdomennya dibandingkan dengan persentase lemak abdomen yang dihasilkan oleh Asmarani (2009) yang menggunakan tepung kunyit dalam pakan ayam broiler, namun masih lebih tinggi jika dibandingkan dengan hasil penelitian Malvin dkk (2017) yang menggunakan mikrokapsul minyak ikan.

Tabel 2. Bobot badan, bobot karkas, persentase karkas, dan persentase lemak abdomen ayam broiler yang diberi tambahan tepung tanaman pegagan

\begin{tabular}{lrrrr}
\hline \multirow{2}{*}{ Parameter } & \multicolumn{4}{c}{ Perlakuan } \\
\cline { 2 - 5 } & \multicolumn{1}{c}{$\mathrm{A}(0 \%)$} & $\mathrm{B}(1.5 \%)$ & $\mathrm{C}(3 \%)$ & $\mathrm{D}(4.5 \%)$ \\
\hline Bobot hidup broiler (g) & $889.0^{\mathrm{ab}}$ & $881.0^{\mathrm{a}}$ & $828.0^{\mathrm{ab}}$ & $944.0^{\mathrm{b}}$ \\
Bobot Karkas (g) & $576.0^{\mathrm{a}}$ & $591.0^{\mathrm{a}}$ & $542.0^{\mathrm{a}}$ & $599.0^{\mathrm{a}}$ \\
Persentase Karkas (\%) & $65.00^{\mathrm{a}}$ & $67.06^{\mathrm{a}}$ & $65.46^{\mathrm{a}}$ & $63.46^{\mathrm{a}}$ \\
Lemak abdomen (\%) $^{*}$ & $1.19 \%^{\mathrm{a}}$ & $1.13^{\mathrm{a}}$ & $1.23^{\mathrm{a}}$ & $1.12^{\mathrm{a}}$ \\
Lemak abdomen (\%) $^{*}$ & $2.05 \%^{\mathrm{a}}$ & $2.09^{\mathrm{a}}$ & $2.26^{\mathrm{a}}$ & $2.24^{\mathrm{a}}$ \\
\hline
\end{tabular}

Data adalah hasil rata-rata dari $n=5$. Huruf superskrip berbeda pada baris yang sama menunjukan berbeda nyata $(\mathrm{p}<0.05)$.

Ket* = pembanding untuk penambahan kunyit sebagai additif pakan broiler (Asmarasari, 2008)

\section{Kesimpulan}

Berdasarkan data yang diperoleh dan penilaian secara statistik dapat disimpulkan bahwa penambahan tepung tanaman pegagan dalam pakan dapat mempengaruhi bobot ayam broiler, namun tidak berpengaruh terhadap bobot karkas, persentase karkas dan persentase lemak abdomennya. Disarankan penambahan 3\% tepung tanaman pegagan dalam pakan untuk memperbaiki performans ayam broiler.

\section{Daftar Pustaka}

Asmarasari, S.A. dan Suprijatna, E. 2008. Pengaruh Penggunaan Kunyit Dalam Ransum Terhadap Performa Ayam Pedaging. Seminar Nasional Teknologi Peternakan dan Veteriner.

Malvin, T., Mirzah, \& Montesqrit. 2017. PENGARUH PEMBERIAN MIKROKAPSUL MINYAK IKAN TERHADAP LEMAK ABDOMEN DAN KADAR 
KOLESTEROL DAGING BROILER. LUMBUNG https://doi.org/10.31227/osf.io/e4gkv

Nur, A.A.K., Devi, M. dan Hidayat, L. 2017. Pengaruh Penambahan Pegagan (Centella asiatica L. Urban) Terhadap Daya Terima dan Mutu Kerupuk. Jurnal Aplikasi (Teknologi Pangan, $6 \quad$ (3) 2017. https://doi.org/10.17728/jatp.238.

Harahap, D.A. 2016. Suplementasi Fitobiotik Pegagan (Centtela asiatica (L) Urban) Dalam Pakan Terhadap Performan Ayam Broiler. Universitas Riau Kepulauan (UNRIKA) Batam. http://download.portalgaruda.org/article.php? Download tanggal 20 Juni 2018.

Siregar, R.A.S., Nurmi, A. dan Hasibuan, M. 2017. Pemberian Ekstrak Pegagan (Centella asiatica) Terhadap Performans Ayam Broiler. Jurnal Peternakan Universitas Muhammadiyah Tapanuli Selatan, Vol.1, No.2 (2017), ISSN Cetak: 2548-3129. http://jurnal.umtapsel.ac.id/index.php/peternakan/article/view/242. Download tanggal 20 Juni 2018. 